\section{ANALYZING THE ROLES OF INDONESIAN IMMIGRATION AGAINST PANDEMIC}

Jurnal Analisa Sosiologi

Juli 2021, 10 (Edisi Khusus

ICOSAPS): $326-343$

\author{
Rizqi Ganis Ashari ${ }^{1}$, Dwi Bima Achmad Setyawan ${ }^{2}$
}

\begin{abstract}
The spread of Coronavirus Disease 2019 (COVID-19) to various regions has initiated the government to formulate public policies to limit its spread. The restrictions to enter and exit a country's territory (lockdown), have become one of the public policies implemented by the governments. Despite the decision to apply lockdown, Indonesia has decided to apply a LargeScale Social Restrictions (PSBB) program to overcome the transmission of COVID-19. The concrete impact of the implementation of the policy is dynamic changes in the Regulation of the Ministry of Law and Human Rights (Permenkumham) which acts as the basis for immigration practice. The study aimed to identify the role of Indonesian Immigration which stands on the four Laws of the ministerial regulations that were specifically formed in response to the spread of COVID-19. Based on a theoretical framework from the perspective of complexity and normative approaches using the Issue, Rule, Analysis/Application, and Conclusion methods, this study has identified a tendency for the role of Indonesian immigration to be adaptive following changes during a pandemic. The dynamics changes of ministerial regulations are formed through the interpretation of various facts. This interpretation has resulted in the gradual role of Indonesian Immigration which increasingly reinforces the regulation regarding the presence of foreigners in Indonesia at every change occurring in ministerial regulations. The implications regarding the adaptive nature of ministerial regulations are discussed further in this study by correlating the role of opinion leaders to minimizing negative images due to intensely changing policies.
\end{abstract}

Keywords: Coronavirus Disease-19, Immigration Role, Public Policy, Complexity Perspective, Adaptive Regulation

\footnotetext{
Abstrak

Penyakit Coronavirus Disease 2019 (COVID-19) yang secara masif mewabah ke berbagai wilayah, mengakibatkan negara-negara di dunia merumuskan kebijakan publik untuk meminimalisir penularannya. Peraturan

1,2, Immigration Office of Ngurah Rai

'ganisashari13@gmail.com

Artikel yang diterbitkan Jurnal Analisa Sosiologi pada edisi khusus ICOSAPS ini telah memenuhi syarat-syarat karya ilmiah, diproses sama seperti pada penerbitan non edisi khusus (terbitan normal), dipresentasikan di International Conference on Social and Political Sciences (ICOSAPS) "Strengthening Resilient Society in the Disruptive Era" yang diselenggarakan oleh Fakultas Ilmu Sosial dan Politik Universitas Sebelas Maret Surakarta pada tanggal 7-8 Oktober 2020.
} 
yang memperketat lalu lintas masyarakat untuk keluar dan masuk wilayah suatu negara (lockdown), menjadi salah satu opsi kebijakan publik yang banyak dipilih. Di tengah maraknya negara-negara di dunia menerapkan lockdown, Indonesia memilih opsi lain berupa Pembatasan Sosial Berskala Besar (PSBB) untuk mengatasi penularan COVID-19 di wilayahnya. Dampak kongkret dari diberlakukannya kebijakan itu adalah perubahan secara dinamis Peraturan Kementerian Hukum dan Asasi Manusia (Permenkumham) yang menjadi landasan atas berlangsungnya praktek keimigrasian. Penelitian ini kemudian bertujuan untuk mengetahui peran Imigrasi Indonesia yang berada pada empat Peraturan Menteri Hukum dan Hak Asasi Manusia yang secara khusus dibentuk untuk merespon COVID19. Dengan menggunakan kerangka teoritik dari perspektif kompleksitas dalam pembuatan kebijakan publik dan pendekatan normatif dengan metode Issue, Rule, Analysis/Application, serta Conclusion, penelitian ini menemukan adanya kecenderungan peran Imigrasi Indonesia bersifat adaptif mengikuti perubahan lanskap sosial di saat pandemi. Dinamika perubahan peraturan menteri itu terbentuk melalui interpretasi terhadap berbagai fakta aktual. Hal ini berjalan melalui empat tahap: 1) pembelajaran, 2) negosiasi persetujuan, 3) transfer gagasan, dan 4) kontekstualisasi. Keempat tahap ini menghasilkan peran Imigirasi Indonesia yang bersifat gradual dan semakin ketat mengatur keberadaan orang asing di Indonesia di setiap perubahan peraturan menteri. Implikasi mengenai sifat adaptif peraturan menteri dibahas lebih jauh di penelitian ini dengan mengaitkan peran opinion leader untuk menimalisir citra negatif akibat kebijakan yang berubah secara intens.

\section{Kata Kunci: Coronavirus Disease-19; Peran Imigrasi, Kebijakan Publik, Perspektif Kompleksitas, Regulasi Adaptif}

\section{INTRODUCTION}

Early in 2020, the world was shocked by the spread of disease. The deadly virus attacking the human respiration system first appeared in Wuhan City, China. The disease, known as COVID-19, is transmitted through the SARS-CoV-2 virus. On March 11, 2020, the World Health Organization (WHO) announced the disease as a pandemic because its spread had reached more than 110 countries and several people were affected by this virus (Ducharme, 2020). Data obtained from the WHO Situation Report-70 (2020e) showed that as of March 30, 2020, 693,282 people were confirmed to have COVID-19 with 33,106 deaths.

The massive spread of COVID-19 has led various countries to formulate certain policies to protect their population. Lockdown is a popular policy adopted by several countries to slow the spread of the disease. For example, the policy of limiting outdoor activities has been carried out by the 
British government, which prohibits its citizens from traveling outside except for urgent needs, starting from March 23, 2020 (Hamzelou, 2020). Besides the United Kingdom, Hamzelou (2020) also recorded that other countries have implemented similar policies, including South Africa, India, Malaysia, Singapore, and the Philippines. In other words, limiting access to the country to reduce the interaction between individuals, whose health record is unknown. Furthermore, the implementation of the lockdown policy has shown some good results. Based on research conducted by Tian et al., (2020), the decision taken by the Government of China to restrict the movement towards people from and to Wuhan City and implement a national emergency response has slowed down the spread of COVID-19 to other cities. Tian et al., (2020) explained that the restriction of the movement towards persons has been able to slow the spread of COVID-19 to another city up to 2.91 days.

Interestingly, while other countries implementing a lockdown policy, Indonesia has implemented another policy. Specifically, Indonesia's President, Joko Widodo, said the lockdown policy was not a strategic step that could be applied for Indonesia to reduce the spread of COVID-19 (Egeham, 2020). Instead of lockdown, President Joko Widodo formulated a PSBB policy to address the massive distribution of COVID-19. Through this policy, the focus is the application of distance both socially and physically, for every citizen (Gian Asmara, 2020). This condition affects immigration practices that regulate the traffic of foreign nationals to enter Indonesian territory.

The article aimed) was to identify the roles of Indonesian Immigration in fighting the spread of COVID-19. The impact on the implementation of some policies to prevent the spread of COVID-19, which is manifested in changes in Permenkumham, especially related to the movement towards persons in Indonesian territory. This article describes the functions of Indonesian Immigration as regulated in Government Regulation Number 6 of 2011 on Immigration article 1 paragraph 3 in the context of maintaining state security, which is applied when Indonesia is dealing with a global pandemic through the changes in Permenkumham. For this reason, the 
research question is: What role does Indonesian Immigration play in dealing with the COVID-19 pandemic?

Before discussing the roles of Indonesian immigration in dealing with the COVID-19 pandemic, the theoretical framework including the assumption of the research will be described by understanding the position of public policy of the pandemic response landscape. In a more specific context, various actions in public policy can be interpreted as an intellectual approach that is multidisciplinary, specifically applied to tackle social problems in society. Later, public policy studies will identify important issues that require governmental measures to be resolved and also analyze the impact on implementing the solutions to the issues (P.deleon in Smith \& Larimer, 2009).

Public policy which can't be separated from social values results in the formulation which is always oriented to certain values. Lasswell explained this as one of the characteristics of public policy (Smith \& Larimer, 2009). For this reason, normatively, various public policy applications are closely related to the formation of a better human life. Moreover, the position of public policy and its value-oriented characteristics tends to make political considerations emerge in the process of formulating each policy. As a result, an issue and how to overcome it is arranged in such a way. The facts of the issue are seen objectively, however, the facts will be filtered by certain systems and values of trust, which are trusted by decision-makers to provide solutions (Smith \& Larimer, 2009).

Linking political public policy tendencies towards pandemic mitigation will encourage the understanding of public policy from the perspective of complexity. This perspective can be interpreted as a point of view that presents the results and behavior of the people obtained from a system that has no order and stability (Cairney, 2012; Room, 2011; Teisman \& Klijn, 2008). The assumption of this theory states that a system is seen not as separated components, but as a unity, which at the same time, the development of the system is influenced by the interaction of the components in it. Thus, when a part of the system is damaged, it will respond independently to the conditions that affect the system, even though the components of the system have never interacted intentionally. 
Emergency responses issued by the system as a whole and its selforganizing nature, are the main characteristics of this perspective in seeing a social phenomenon.

For example, the World Bank stated that the economic sector is one of the sectors that have the potential to be affected by a pandemic if pandemic countermeasures are not taken. Specifically, these impacts can be categorized as 1) decreased workforce due to pandemic death, 2) decreased worker productivity due to pandemic impact, 3) resource priorities shifting to pandemic response, and 4) changes in individual community behavior (Gong, Zhang, Yuan, \& Chen, 2020:2). Meanwhile, productivity is one of the keys to economic growth. Accurate solutions are urgently needed, otherwise, these conditions can lead to economic pressures.

The discussions related to economic damage caused by a pandemic are not the first time. The Journal of the World Bank entitled Pandemic Risk written by Jonas (2014), describes the economic loss resulting from the pandemic. In that journal, Jonas (2014) explains that the Spanish flu pandemic could cost $\$ 3$ trillion of the world's PDB where $60 \%$ is used for prevention and control measures. Jonas (2014) added that only a moderate flu pandemic could impact half of the total losses when the Spanish flu occurred. Another example is a weak pandemic such as the H1N1 flu in 2009, which could have an economic impact on less than 0.5 percent of GDP globally. Pandemic risk has an annual expected value of an order of magnitude of $\$ 30$ billion, which is equivalent to more than one-fifth of the average annual losses from all disasters in the past decade (Jonas, 2014).

Another thing to consider, within a complexity perspective, the domino effect of the massive spread of COVID-19 which has the potential to create an economic crisis as illustrated with the example of, encourages institutions in government to make changes. This change can only be done, when the macro-political institutions in government are aware of the damage to the ongoing subsystem activities (Bovaird, 2008). This change takes place by adjusting the concept of punctuated equilibrium. This means that change occurs gradually and adaptively, starting with the number of small changes in the system, large-scale moderate changes, and also the tendency to appear large-scale changes if this occurs to certain 
circumstances (Bovaird, 2008; Swanson et al., 2009). Thus, the complexity perspective offers various theoretical foundations for understanding the process of public policies creation in conditions that are easy to change from the analysis carried out based on a certain time (Morçöl \& Wachhaus, 2009; Teisman \& Klijn, 2008).

Next, the application of the complexity perspective of observing pandemic situations will create several conditions. According to Cairney (2012), the logic of causality in the law that occurs to normal life (i.e., action $\mathrm{X}$ is appropriate if $\mathrm{Y}$ occurs), cannot be done because the context of the pandemic is different from normal circumstances. In addition, the nature of systems that can organize themselves independently makes it difficult to control because the changes that occur due to internal or external impetus cannot be used as a basis for formulating a policy. As a result, the interventions hardly produce optimal policies.

Moreover, the pandemic will create an unstable landscape, so that policymakers are recommended not to relying on one policy (Teisman and Klijn in Cairney, 2012). These assumptions urge the government or related agencies to adapt to think of strategies in providing solutions to any changes that occur. Meanwhile, a policy is considered to be adaptive if it has three conditions, namely: 1) integrated and continuous analysis, including scenario planning, 2) multi-party deliberations for the analysis of bad potentials and unintended consequences, and 3) monitoring key performance indicators to trigger automatic policy adjustments (Runnalls \& Pachauri, 2009). Based on the description, it can be argued that the role of Indonesian Immigration in the formulation of adaptive policies which were formulated in a short time, focused on COVID-19 issues, and integrated with other institutions.

\section{RESEARCH METHODE}

This study employed a normative approach to determine the role of Indonesian immigration in dealing with the COVID-19 pandemic. the Normative approach can be defined as an approach that explains the application of laws on a particular issue (Dobinson \& Francis, 2007). This approach is also known as the doctrinal approach which specifically 
scrutinizes the principles and systematics of law, legal synchronization, the history of law, and comparative regulations (Christiani, 2016). Research within the scope of the normative approach will endeavor to interpret various legal doctrines contained in legal documents. The interpretation process is carried out through a method that becomes the research standard (Van Hoecke, 2011).

Furthermore, Puttman (in Sonata, 2014) explained the normative approach as a method carried out by the Issue, Rule, Analysis/Application, and Conclusion (IRAC) aspects of each legal source. The analysis was conducted on four Permenkumham which were established to limit the spread of COVID-19 through the immigration sector (i.e., Permenkumham No.3 of 2020, Permenkumham No.7 of 2020, Permenkumham No.8 of 2020, and Permenkumham No. 11 of 2020). Secondary data onto the forms of literature references or various reviews in the mass media were also used to specifically explain data regarding the implementation of these Permenkumham.

\section{RESULT AND DISCUSSION}

To deal with the COVID-19 pandemic, the Ministry of Law and Human Rights formulated four ministerial regulations that accommodate policies related to foreign citizen traffic in the Indonesian territory. Figure 1. shows the rationale for the making of the four ministerial regulations enacted from February to March. Furthermore, from the analysis that has been conducted, this study found the adaptive nature of each Permenkumham was formed by adjusting the conditions of the spread of COVID-19. This adaptive nature makes each existing ministerial regulation different from the previous ministerial regulations. This can be seen by observing each Permenkumham which is shown in Table 1. and Table 2. In addition, the application of each rule for Permenkumham also has different implications. It indicates that each regulation is dynamic in adjusting to the uncertainties that arise out of the COVID-19 pandemic.
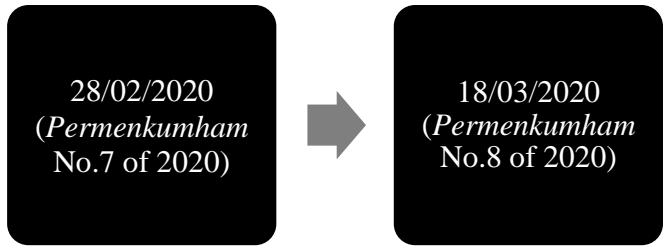
Based on the results of the analysis conducted on the four ministerial regulations above, it can be concluded that the actions which have been done by Indonesian Immigration are the application of complexity perspective in dealing with an unstable environment. The four regulations illustrate the ever-changing role of Indonesian Immigration in adjusting to the very dynamic social landscape of the pandemic. This is in line with the analysis predicted by Rhodes (2008). According to him, in a social landscape that is dynamic and involves heterogeneous parties, the application of complex adaptive systems in the formulation of public policies becomes a realistic choice. The choice will require an agent in public policy to create adaptive actions in urgent situations (Rhodes, 2008). The concept has been elaborated further by Rhodes (2008) in his research on the implementation of the concept of emergence as part of the theory of complexity of the regeneration program of urban areas in Northern Ireland and the Republic of Ireland. Although it has a different context of the research that has been done, the research has produced important findings to the urgent regulations arising from the interaction of each stakeholder in the six areas that were the focus on the regeneration project.

His research proves that new public policies are established in the forms of 1) interactive (i.e., regulating agent behavior in certain social landscapes), 2) expansion of the arena (i.e., rules that expands the regeneration projects agenda), to 3 ) implementation rules that are negotiable and resolutive when the process of repairing and adding public facilities triggers a conflict of resistance in the surrounding community (i.e., such as the construction of a toll road both going to Maupu and the Ballymun area) (Rhodes, 2008). These various regulations developed from fundamental regulations in the institutional environment where each jurisdiction (i.e., both the Republic of Ireland and Northern Ireland) has specific laws about where the urban regeneration program is carried out and who is responsible. This proves, like the change in the role of Indonesian Immigration, in the implementation of public policies, a complex system will adapt to such a way as to accomodating various interests in the people, so that the main objectives of the policy can be achieved. 
Furthermore, the development and change from the public policy of a complex period confirm the tendency towards the system to interpret historical and actual data (Haynes, 2008). This is part of the feedback and interactive processes in the system. Relating the stage to the implementation of four ministerial regulations that gradually limits foreigners from entering Indonesian territory, one of the historical data onto the establishment of the policy is Law No. 6 of 2011 on Immigration which was enacted long before the pandemic took place. 
Tabel 1. Comparation of Permenkumham No.3 of 2020 and Permenkumham No. 7 of 2020

\begin{tabular}{|c|c|c|c|c|}
\hline & Issue & Rule & Analysis/Application & Conclusion \\
\hline $\begin{array}{l}\text { Permenkumham } \\
\text { No. } 3 \text { of } 2020\end{array}$ & $\begin{array}{l}\text { 1. WHO (2020b) stated } \\
\text { COVID-19 had } \\
\text { infected 20,417 } \\
\text { people in China and } \\
159 \text { people outside } \\
\text { the country. } \\
\text { 2. WHO (2020a) } \\
\text { announced COVID- } \\
19 \text { a Public Health } \\
\text { Emergency of } \\
\text { International } \\
\text { Concern. }\end{array}$ & $\begin{array}{l}\text { 1. } \\
\text { Restriction on traffic activities for } \\
\text { some foreigners (article } 2-3 \text { ). } \\
\text { 2. Accommodates Force Majeure } \\
\text { Permits for Chinese citizens (article } \\
\text { 5, paragraph 1-5). }\end{array}$ & 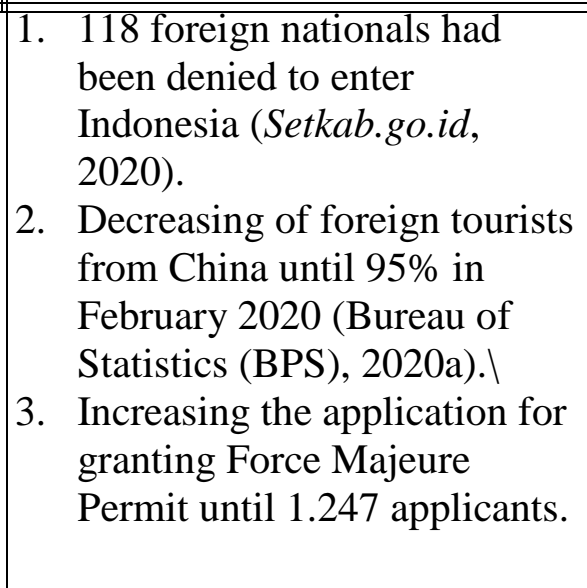 & $\begin{array}{l}\text { 1. Protection for } \\
\text { Indonesian through } \\
\text { rejection of foreign } \\
\text { nationals who have } \\
\text { visited China in the } \\
\text { past } 14 \text { days. } \\
\text { 2. Granting Force } \\
\text { Majeure Permit for } \\
\text { Chinese people who } \\
\text { can't return to their } \\
\text { countries. }\end{array}$ \\
\hline $\begin{array}{l}\text { Permenkumham } \\
\text { No. } 7 \text { of } 2020\end{array}$ & $\begin{array}{l}\text { 1. Based on WHO } \\
\text { Situation Report - } 39 \\
\text { (2020c), the status of } \\
\text { the impact of } \\
\text { COVID-19 spread in } \\
\text { the world was at a } \\
\text { very high level. }\end{array}$ & $\begin{array}{l}\text { 1. Limiting the granting of Exemption } \\
\text { Visa and Visa on Arrival for } \\
\text { foreigners, who have lived and/or } \\
\text { visited China within } 14 \text { days before } \\
\text { entering Indonesia (article } 2 \text { ). } \\
\text { 2. Foreigners should have several } \\
\text { additional certificates (article } 3 \\
\text { paragraph } 2 \text { - paragraph } 3 \text { ). } \\
\text { 3. The addition categories of foreigners } \\
\text { for Force Majeure Permit (article 4). }\end{array}$ & $\begin{array}{l}\text { 1. } 24 \text { February } 2020 \text { to } 05 \\
\text { March } 2020 \text { emergency } \\
\text { residence permit applicants } \\
\text { reached } 1396 \text { (Nuraini, } \\
\text { 2020). } \\
\text { 2. From 6 February } 2020 \text { - } 10 \\
\text { March 2020, } 126 \text { foreigners } \\
\text { were refused their entry to } \\
\text { Indonesia related to their } \\
\text { travel history to China } \\
\text { (Nurita, 2020). }\end{array}$ & $\begin{array}{l}\text { 1. The establishment of } \\
\text { this regulation } \\
\text { strengthens the roles } \\
\text { of Indonesian } \\
\text { Immigration in } \\
\text { dealing with COVID- } \\
19 \text { compared to the } \\
\text { existence of the } \\
\text { previous ministerial } \\
\text { regulation. }\end{array}$ \\
\hline
\end{tabular}

Source: Authors 
Tabel 2. Comparation of Permenkumham No.8 of 2020 and Permenkumham No. 11 of 2020

\begin{tabular}{|c|c|c|c|c|}
\hline $\begin{array}{l}\text { Permenkumham } \\
\text { No. } 8 \text { of } 2020\end{array}$ & $\begin{array}{l}\text { 1. Announcement from } \\
\text { WHO Situation } \\
\text { Report - 51 (WHO, } \\
\text { 2020d) about the } \\
\text { global health status } \\
\text { as a pandemic. }\end{array}$ & $\begin{array}{l}\text { 1. Temporary suspension of the } \\
\text { issuance of Exemption Visa (article } \\
\text { 2) and Visa on Arrival (article 3), } \\
\text { while allowing foreigners with a } \\
\text { certain urgency to visit Indonesia by } \\
\text { first applying for a visa through a } \\
\text { Representative of the Republic of } \\
\text { Indonesia abroad (article 4). } \\
\text { 2. Providence of Force Majeure } \\
\text { Permits and other facilities for } \\
\text { foreigners affected by a lockdown } \\
\text { policy without specifically } \\
\text { categorizing their citizenship (article } \\
\text { 5). }\end{array}$ & $\begin{array}{l}\text { 1. Visa's temporary suspension } \\
\text { has a major impact on some } \\
\text { sectors (e.g., foreign tourists } \\
\text { in Bali dropped dramatically) } \\
\text { (BPS, 2020b). } \\
\text { 2. Foreigners do not need to } \\
\text { apply for force majeure } \\
\text { permits. A fee will be } \\
\text { charged at Rp. } 0.00 \text { (zero } \\
\text { rupiahs). }\end{array}$ & $\begin{array}{l}\text { 1. The establishment of } \\
\text { Permenkumham No. } 8 \\
\text { of } 2020 \text { strengthens } \\
\text { the role of Indonesian } \\
\text { Immigration in } \\
\text { dealing with COVID- } \\
19 \text { compared to } \\
\text { previous regulations. }\end{array}$ \\
\hline $\begin{array}{l}\text { Permenkumham } \\
\text { No. } 11 \text { of } 2020\end{array}$ & $\begin{array}{l}\text { First COVID-19 } \\
\text { case in Indonesia } \\
\text { revealed by } \\
\text { President Joko } \\
\text { Widodo on March 2, } \\
\text { 2020 (Nugroho, } \\
\text { 2020) }\end{array}$ & $\begin{array}{l}\text { 1. Foreigners cannot re-enter } \\
\text { Indonesia's territory except for some } \\
\text { categories (article } 2 \text { and article } 3 \\
\text { paragraph } 1 \text { - paragraph } 2 \text { ). } \\
\text { 2. Automatic granting of residence } \\
\text { permits to strengthen previous policy } \\
\text { (article } 4 \text { and article 5). }\end{array}$ & $\begin{array}{l}\text { 1. The Immigration Checkpoint } \\
\text { both at the airport and the } \\
\text { port less crowded than } \\
\text { before. Most flights are } \\
\text { evacuation and repatriation } \\
\text { flights (Cahyani, 2020). }\end{array}$ & $\begin{array}{l}\text { 1. Temporary banning on } \\
\text { foreigners } \\
\text { visiting/transiting } \\
\text { Indonesian territory (with } \\
\text { certain exceptions). } \\
\text { 2. Providing the facility for } \\
\text { granting free Force } \\
\text { Majeure Permits to } \\
\text { foreigners whose } \\
\text { residency permits have } \\
\text { been expired. }\end{array}$ \\
\hline
\end{tabular}

Source: Authors 
Article 13 Paragraph F of the law affirms the authority of the Immigration Officer to refuse foreigners that suffer from infectious diseases that can endanger the health of the general public. This article becomes a fundamental part of the formulation of the role of Indonesian Immigration to prevent the spread of COVID-19 in Indonesian territory.

In addition, in the context of COVID-19 countermeasures, the process of interpreting the actual data by a system goes through several stages. Weible et al., (2020) explain the ongoing changes in regulations to deal with a pandemic starting from 1) the learning process, 2) the process of negotiating agreements, 3 ) the transfer of ideas between governments, and ended with 4) the process of codifying decisions on various contextual factors (i.e., institutional factors, cultural orientation, economic conditions to the political style of a country). If the explanation for the process of changing public policy is related to the findings in this study, it can be argued that there is a match between the process and the adaptive roles of Indonesian immigration.

The learning process is characterized by the rules that gradually change from the aspect of mitigation to a complete ban on community activities because the level of transmission of COVID-19 is growing exponentially (Weible et al., 2020). The response appears in the form of changes in the subject of the refusal of foreign citizens of transit or visit in Indonesia which is increasingly stringent in every ministerial regulation. For example, one of the roles of the Indonesian Immigration in Permenkumham No. 3 of 2020 is a rejection of Chinese citizens and foreign nationals who in the past 14 days (before entering the territory of Indonesia), have visited China. Interestingly, the rules changed when the Ministry of Law and Human Rights studied the actual spread of COVID-19 disease which took place massively in various countries. This result of the study has provided a foundation for the formation of more stringent rules for the prohibition on entry into) foreign nationals and the termination of certain types of visas in the next ministerial regulation. As a result, the role of Immigration in Permenkumham No. 11 of 2020 changed into a temporary ban on foreigners to visit/transit in the territory of Indonesia without specifically categorizing the foreign nationality. This proves that the adaptive process of a system to 
environmental conditions through the learning stage encourages the system to create its perceptions and actions to deal with the social landscape in which it is located (Teisman \& Klijn, 2008).

The facts obtained in the learning phase are also used as the basis of the approval negotiation stage. According to Weible et al., (2020), this stage will produce several stimulus packages that are formed to help people affected by COVID-19. In the context of the role of Indonesian Immigration, this stage of negotiations produced various facilities for foreigners that were already in Indonesia, whose journey outside of Indonesia was affected by COVID-19. For example, Permenkumham No. 3 of 2020 regulates Chinese citizens who are in that situation, administering force major permits which allows them to stay longer in Indonesia without being charged an overstayed fee. By continuing to learn the facts that occur, this stimulus also develops in every change in ministerial regulations. The facility is increasingly public, so that every foreigner in Indonesia who is in the same situation, can get a stay permit without being restricted by certain nationalities.

In addition, the stimulus as a manifestation of the negotiation stage is also closely related to Indonesia's external relations with other countries. The global relations make the Indonesian government identify the way other countries enforce their immigration policies such as the strict quarantine and restrictions that have been carried out by China and other countries (Weible et al., 2020), have indirectly also contributed as a motivating factor of the existence of a stimulus in the form of force major permits. Explicitly, Permenkumham No. 8 of 2020 mentioned the stimulus as one of the things considered to provide legal certainty for foreigners whose journey to leave Indonesia was affected by the lockdown policy in a country. The policies of other countries present as external events that can cause changes that unexpectedly determine the dynamics of public policy (van Buuren \& Gerrits, 2008:384). In the final stage, all regulations resulting from the changes are still contextualized in the corridor of the main tasks and functions as the Ministry of Law and Human Rights in general and the Directorate General of Immigration in particular. 
Another thing to consider, the role of the Indonesian Immigration which is very adaptive in dealing with the spread of COVID-19 has the potential to create other implications at some point. Although it produces an adaptive system to historical and facts, changes from ministerial regulations in a short time tend to produce a negative image of the inconsistency of public policy to accommodate an issue. Instead of providing legal certainty, a very rapid change in a public policy will produce uncertainty, especially regarding how long this regulation applies and which regulations will be permanent (Weible et al., 2020).

For that reason, this research formulates a recommendation of the form of an increase in the role of opinion leaders that are expected to have an impact to minimize the negative image of the uncertainty that arises due to the intense changes in the policy of ministerial regulations in immigration. In this case, the opinion leaders can be interpreted as people with good communication skills and knowledge of a field and able to influence others in certain environmental conditions and supported by a wide communication network (Winter \& Neubaum, 2016). With its ability, opinion leaders are expected to be able to communicate various realities and possibilities to gain trust from the public (Jamal \& Abu Bakar, 2015). The opinion leader will enable the public to understand the background of the process of formulating immigration regulations that have changed adaptively as the right decision in a pandemic situation that is full of uncertainties.

\section{CONCLUSION}

The massive spreading of COVID-19 throughout the world has resulted in policies established by many countries to limit the spread of the disease. Regional quarantine and lockdown policies were taken into action by various countries to reduce the interaction of citizens whose medical history is unknown. Instead of applying a similar policy, Indonesia has established a PSBB policy to address the massive spread of COVID-19. The decision has an impact on immigration practices that regulate the traffic of foreign nationals to enter Indonesian territory. For this reason, the study aimed to determine the roles of Indonesian Immigration in dealing with the COVID19 pandemic. 
The findings in this study indicate that the roles of Indonesian Immigration are adaptive to the changes in ministerial regulations. Adaptive change means adjusting various changes in social landscapes (i.e., number of countries affected, the number of victims of COVID-19 globally, as well as the increasing number of countries implementing lockdown policies) due to the pandemic. In general, in each ministerial regulation, the role of immigration can be categorized into 1) rejecting foreigners and 2) providing Force Majeure Permits for foreigners whose trips are affected by lockdown policies in other countries. The adaptive nature of each ministerial regulation results in the gradual changes of the roles of Indonesian Immigration which establishes more selective regulations regarding the presence of foreigners in Indonesia. Finally, the very rapid adaptive nature of the change in ministerial regulation has the potential to create a negative image of the inconsistency of public policies. This study recommends strengthening the role of opinion leaders that can influence public opinion. The expectation from the presence of opinion leaders in the formation of public trust related to the formulation of adaptive regulations as the right decision to deal with an unstable pandemic situation.

\section{References}

Badan Pusat Statistik. 2020a. Jumlah Kunjungan Wisman Menurut Kebangsaan dan Bulan Kedatangan Tahun 2017 - 2020. Retrieved from https://www.bps.go.id/dynamictable/2018/07/30/1548/jumlahkunjung an-wisman-menurut-kebangsaan-dan-bulan-kedatangantahun-2017---2020.html. Accessed on 20 April 2020.

Badan Pusat Statistik. 2020b. Jumlah Wisatawan Asing ke Bali Menurut Pintu Masuk 2009-2020. Retrieved from https://bali.bps. go.id/statictable/2018/03/05/46/jumlah-wisatawan-asing-ke-bali-menu rut-pintu-masuk-2009-2020.html. Accessed on 21 April 2020.

Bovaird, T. 2008. Emergent Strategic Management and Planning Mechanisms in Complex Adaptive Systems. Public Management Review, 10, (3): 319-340.

Cahyani, D. R. 2020. Angkasa Pura I: 4.960 WNI Pekerja Migran Kembali ke RI Lewat Bali. Tempo.co. 6 May. Retrieved from https://bisnis.tempo.co/read/1339081/angkasa-pura-i-4-960-wni-peker ja-migran-kembali-ke-ri-lewat-bali. Accessed on 10 May 2020.

Cairney, P. 2012. Complexity Theory in Political Science and Public Policy. Political Studies Review, 10: 346-358.

Christiani, T. A. 2016. Normative and Empirical Research Methods: Their Usefulness and Relevance in the Study of Law as an Object. Procedia - Social and Behavioral Sciences, 219, (2016): 201-207. 
Dobinson, I., \& Francis, J. Qualitative Legal Research. In M. McConville \& W. H. Chui (Eds.). 2007. Research Methods for Law. Edinburgh: Edinburgh University Press.

Ducharme, J. 2020. World Health Organization Declares COVID-19 a "Pandemic." Here's What That Means. Time. 11 Maret, Retrieved from https://time.com/5791661/who-coronavirus-pandemic-declarati on/ Accessed on 20 April 2020.

Egeham, L. 2020. Jokowi: Lockdown Itu Orang Tak Boleh Keluar Rumah, Transportasi Dihentikan. Liputan6. 1 April. Retrieved from https://www.liputan6.com/news/read/4216704/jokowi-lockdown-ituorang-tak-boleh-keluar-rumah-transportasi-dihentikan. Accessed on $19^{\text {th }}$ April 2020.

Gian Asmara, C. 2020. Ini Lho Penjelasan dari Jokowi Soal Perbedaan Lockdown \& PSBB. CNBCIndonesia.com. 1 April. Retrieved from https://www.cnbcindonesia.com/news/20200401150116-4149088/ ini-lho-penjelasan-dari-jokowi-soal-perbedaan-lockdown-psbb. Accessed on 15 April 2020.

Gong, B., Zhang, S., Yuan, L., \& Chen, K. Z. 2020. A balancing act: minimizing economic loss while controlling novel coronavirus pneumonia. Journal of Chinese Governance, 5, (2): 249-268.

Hamzelou, J. 2020. World in lockdown. New Scientist, 245, (3275): 7.

Haynes, P. 2008. Complexity Theory and Evaluation in Public Management. Public Management Review, 10, (3): 401-419.

Jamal, J., \& Abu Bakar, H. 2017. The Mediating Role of Charismatic Leadership Communication in a Crisis: A Malaysian Example. International Journal of Business Communication, 54, (4): 369-393.

Jonas, Olga B. 2014. Risk Pandemic. World Bank Development Report Background Papers, 2. http://hdl.handle.net/10986/16343.

Morçöl, G., \& Wachhaus, A. 2009. Network and Complexity Theories: A Comparison and Prospects for a Synthesis. Administrative Theory \& Praxis, 31, (1): 44-58.

Nugroho, R. S. 2020. Rekap Kasus Corona Indonesia Selama Maret dan Prediksi di Bulan April. Kompas.com. 31 Maret, Retrieved from https://www.kompas.com/tren/read/2020/03/31 /213418865/rekapkasus-corona-indonesia-selama-maret-dan-prediksi-di-bulanapril?page $=1$. Accessed on 2 April 2020.

Nuraini, D. 2020. 2.643 WN China Dapat izin Tinggal Terpaksa di Indonesia. Bisnis.com. 5 Maret, Retrieved from https://kabar24.bisnis.com/read /20200305/15/1209706/2.643-wnchina-dapat-izin-tinggal-terpaksa-di-indonesia. Accessed on 6 April 2020.

Nurita, D. 2020. Imigrasi Sudah Deportasi 126 WNA Guna Cegah Penyebaran Corona. Tempo.co. 12 Maret, Retrieved from https: //nasional.tempo.co/read/1318697/imigrasi-sudah-deportasi-126-wna -guna-cegah-penyebaran-corona. Accessed on 6 April 2020.

Rhodes, M. L. 2008. Complexity and Emergence in Public Management. Public Management Review, 10, (3): 361-379.

Room, G. 2011. Complexity, Institutions and Public Policy: Agile DecisionMaking in a Turbulent World. Cheltenham: Edward Elgar Publishing Company. 
Runnalls, D., \& Pachauri, R. K. Forewords. In S. D. \& S. Bhadwal (Eds.). 2009. Creating Adaptive Policies A Guide for Policy-Making in An Uncertain World. New Delhi: SAGE Publications India.

Sekertariat Kabinet Republik Indonesia. 2020. Imigrasi Indonesia Telah Cegah 126 WNA Masuk dari Bandara. Retrieved from https://setkab.go.id/imigrasi-indonesia-telah-cegah-126-wna-masukdari-bandara/. Accessed on 6 May 2020.

Smith, K. B., \& Larimer, C. W. 2009. The Public Policy Theory Primer. Colorado: Westview Press.

Sonata, D. 2015. Metode Penelitian Hukum Normatif dan Empiris: Karakteristik Khas dari Metode Meneliti Hukum. FIAT JUSTISIA:Jurnal Ilmu Hukum, 8, (1): 15-35.

Swanson, Darren, Barg, S., Tyler, S., Venema, H. D., Tomar, S., Bhadwal, S., ... Drexhage, J. Seven Guidelines for Policy-making in an Uncertain World. In: D. Swanson \& S. Bhadwal (Eds.). 2012. Creating Adaptive Policies A Guide for Policy-Making in An Uncertain World. New Delhi: SAGE Publications India.

Teisman, G. R., \& Klijn, E.-H. 2008. Complexity Theory and Public Management. Public Management Review, 10, (3): 287-297.

Tian, H., Liu, Y., Li, Y., Wu, C.-H., Chen, B., Kraemer, M., ... Dye, C. (2020). An investigation of transmission control measures during the first 50 days of the COVID-19 epidemic in China. Science, 368 (6491):638-642.

van Buuren, A., \& Gerrits, L. 2008. Decisions as Dynamic Equilibriums in Erratic Policy Processes. Public Management Review, 10, (3): 381399.

Van Hoecke, M. Legal Doctrine: Which Method(s) for What Kind of Discipline. In M. Van Hoecke (Ed.). 2014. Methodologies of legal research: which kind of method for what kind of discipline? Oxford: Hart Publishing.

Weible, C., Nohrstedt, D., Cairney, P., Carter, D., Crow, D., Durnová, A., ... Stone, D. 2020. COVID-19 and The Policy Sciences: Initial Reactions and Perspectives. Policy Sciences, 53: 225-241.

Winter, S., \& Neubaum, G. 2016. Examining Characteristics of Opinion Leaders in Social Media: A Motivational Approach. Social Media and Society, 2, (3): 1-12.

World Health Organization. 2020a. Statement on the second meeting of the International Health Regulations (2005) Emergency Committee regarding the outbreak of novel coronavirus (2019-nCoV). Retrieved from https://www.who.int/news-room/detail/30-01-2020-statementon-the-second-meeting-of-the-international-health-regulations(2005)-emergency-committee-regarding-the-outbreak-of-novelcoronavirus-(2019-Nov). Accessed on 18 April 2020.

World Health Organization. 2020b. Situation Report 15. Retrieved from https://www.who.int/docs/default-source/coronaviruse/situationreports/20200204-sitrep-15-ncov.pdf?sfvrsn=88fe8ad6_4. Accessed on 20 April 2020.

World Health Organization. 2020c. Situation Report 39. Retrieved from https://www.who.int/docs/default-source/coronaviruse/situationreports/20200228-sitrep-39-covid-19.pdf?sfvrsn=5bbf3e7d_4. 
Accessed on 18 April 2020.

World Health Organization. 2020d. Situation Report 51. Retrieved from https://www.who.int/docs/default-source/coronaviruse/situationreports/20200311-sitrep-51-covid-19.pdf?sfvrsn=1ba62e57_10. Accessed on 2 May 2020.

World Health Organization. 2020e. Situation Report 70. Retrieved from https://www.who.int/docs/default-source/coronaviruse/situationreports/20200330-sitrep-70-covid-19.pdf?sfvrsn=7e0fe3f8_4. Accessed on 7 May 2020. 